\title{
Carbon, metals, and grain size correlate with bacterial community structure in sediments of a high arsenic aquifer
}

\author{
Teresa M. Legg ${ }^{1}$ *, Yan Zheng ${ }^{2,3}$, Bailey Simone ${ }^{4}$, Kathleen A. Radloff ${ }^{3}$, Natalie Mladenov ${ }^{5}$, \\ Antonio González ${ }^{6}$, Dan Knights ${ }^{6}$, Ho Chit Siu ${ }^{2,7}$, M. Moshiur Rahman ${ }^{2}$, K. Matin Ahmed $^{8}$, \\ Diane M. McKnight ${ }^{4}$ and Diana R. Nemergut ${ }^{9}$ \\ ${ }^{1}$ Department of Ecology and Evolutionary Biology, The Institute of Arctic and Alpine Research, University of Colorado, Boulder, CO, USA \\ 2 Queens College, City University of New York, Flushing, NY, USA \\ ${ }^{3}$ Lamont-Doherty Earth Observatory, Columbia University, Palisades, NY, USA \\ ${ }^{4}$ Department of Civil, Environmental and Architectural Engineering, The Institute of Arctic and Alpine Research, University of Colorado, Boulder, CO, USA \\ ${ }^{5}$ The Institute of Arctic and Alpine Research, University of Colorado, Boulder, CO, USA \\ ${ }^{6}$ Department of Computer Science, University of Colorado, Boulder, CO, USA \\ 7 Bronx High School of Science, Bronx, NY, USA \\ ${ }^{8}$ Department of Geology, Dhaka University, Dhaka, Bangladesh \\ ${ }^{9}$ Program for Environmental Studies, The Institute of Arctic and Alpine Research, University of Colorado, Boulder, CO, USA
}

\section{Edited by:}

Rich Boden, University of Plymouth, UK

\section{Reviewed by:}

Hongchen Jiang, China University of

Geosciences Beijing, China

Richard S. Winder, Natural Resources

Canada, Canada

\section{*Correspondence:}

Teresa M. Legg, The Institute of Arctic and Alpine Research, University of

Colorado, Campus Box 450, Boulder, CO 80309-0450, USA.

e-mail: teresa.legg@colorado.edu
Bacterial communities can exert significant influence on the biogeochemical cycling of arsenic (As). This has globally important implications since As in drinking water affects the health of over 100 million people worldwide, including in the Ganges-Brahmaputra Delta region of Bangladesh where geogenic arsenic in groundwater can reach concentrations of more than 10 times the World Health Organization's limit. Thus, the goal of this research was to investigate patterns in bacterial community composition across gradients in sediment texture and chemistry in an aquifer with elevated groundwater As concentrations in Araihazar, Bangladesh. We characterized the bacterial community by pyrosequencing $16 \mathrm{~S}$ rRNA genes from aquifer sediment samples collected at three locations along a groundwater flow path at a range of depths between 1.5 and $15 \mathrm{~m}$. We identified significant differences in bacterial community composition between locations in the aquifer. In addition, we found that bacterial community structure was significantly related to sediment grain size, and sediment carbon $(\mathrm{C})$, manganese $(\mathrm{Mn})$, and iron ( $\mathrm{Fe}$ ) concentrations. Deltaproteobacteria and Chloroflexi were found in higher proportions in silty sediments with higher concentrations of $\mathrm{C}, \mathrm{Fe}$, and $\mathrm{Mn}$. By contrast, Alphaproteobacteria and Betaproteobacteria were in higher proportions in sandy sediments with lower concentrations of $C$ and metals. Based on the phylogenetic affiliations of these taxa, these results may indicate a shift to more Fe-, Mn-, and humic substance-reducers in the high $\mathrm{C}$ and metal sediments. It is well-documented that $\mathrm{C}, \mathrm{Mn}$, and Fe may influence the mobility of groundwater arsenic, and it is intriguing that these constituents may also structure the bacterial community.

Keywords: arsenic, aquifer, bacteria, pyrosequencing, Deltaproteobacteria, Chloroflexi

\section{INTRODUCTION}

Throughout the last decade considerable research effort has focused on characterizing the mechanisms leading to elevated groundwater arsenic (As) concentrations in aquifers throughout South Asia. These studies have demonstrated that groundwater As mobility is affected by a number of factors including redox conditions (Zheng et al., 2004), sediment properties (Winkel et al., 2008), hydrology (Polizzotto et al., 2005), organic matter quality (Mladenov et al., 2010; Neumann et al., 2010), and microbial activity (Islam et al., 2004; Dhar et al., 2011). In the GangesBrahmaputra delta (GBD) region of Bangladesh, where groundwater As concentrations are on average about 10 times higher than the World Health Organization's drinking water guideline value, groundwater As concentrations are heterogeneous (van Geen et al., 2003) and often decoupled from bulk sediment As concentrations (Dhar et al., 2008). In the GBD, areas with high groundwater
As concentrations typically share similar sediment characteristics, hydrology, and organic matter chemistry. Sediment layers within aquifers containing higher proportions of fine-grained material such as silts generally feature higher groundwater As concentrations than sands (van Geen et al., 2006a), which, by contrast, tend to have lower organic matter concentrations. Silty layers have a lower permeability, thereby favoring the accumulation of dissolved As in the groundwater (van Geen et al., 2006b). In addition, finegrained sediments often exhibit higher concentrations of sediment organic matter and metals including iron ( $\mathrm{Fe})$, manganese $(\mathrm{Mn})$, and As (McArthur et al., 2004), which may fuel relevant microbial processes.

Indeed, it is clear that microbial processes are also important in regulating As mobilization in the GBD (Islam et al., 2004; Radloff et al., 2008). Groundwater As mobilization may be enhanced in fine sediments, as microorganisms pair the oxidation 
of organic carbon (C) to the reductive dissolution of Fe-oxides (Lovley and Phillips, 1988), which liberates As from Fe-oxide mineral surfaces (Cummings et al., 1999; McArthur et al., 2001; Tufano and Fendorf, 2008). To a lesser extent, the desorption of As from the microbial reduction of $\mathrm{Mn}$ oxides may also promote elevated As concentrations (Inskeep et al., 2002; Luna et al., 2009), and the release of reduced $\mathrm{Mn}$ into groundwater often occurs with the release of As (Zheng et al., 2004; van Geen et al., 2006b). In addition, microorganisms reduce humic substances (HS; Mladenov et al., 2010) which promotes an electron cascade resulting in Fe-oxide reduction and As desorption (Kappler et al., 2004; Jiang and Kappler, 2008), as well as the reduction of $\mathrm{As}(\mathrm{V})$ to the more mobile As(III; Jiang et al., 2009). Microorganisms can also enhance As mobility in anaerobic aquifers by mediating redox reactions with As. Specifically, the detoxification pathway encoded by the ars operon (Rosen et al., 1991; Macy et al., 2000; Sun et al., 2004) and dissimilatory $\mathrm{As}(\mathrm{V})$ reduction (Saltikov and Newman, 2003) results in the reduction of As(V) to As(III). Also, microorganisms transform As species during methylation (Mukhopadhyay et al., 2002) although evidence of methylation has not been observed in the GBD environment (Islam et al., 2004). By contrast, microbial sulfate reduction can decrease the mobility of As in groundwater (Kirk et al., 2004; Saalfield and Bostick, 2009). Sulfide coprecipitates with As(III) and Fe to form As trisulfide (Newman et al., 1997) under anoxic, reducing conditions (Rittle et al., 1995). Given the diverse array of microbial metabolisms with potential affects on As cycling, a better understanding of the patterns in microbial community structure across sediment characteristics could help elucidate the roles of specific taxa involved in biogeochemical processes that affect As mobility in these anaerobic aquifers.

Recent research investigating the role of microbial communities in groundwater As cycling has used molecular phylogenetic tools to characterize the taxonomic composition of microbial communities in the GBD groundwater environment. The analysis of SSU rRNA gene sequences from microcosm experiments with As-rich aquifer sediment show the addition of a labile $\mathrm{C}$ source promotes bacterial community shifts characterized by an increased proportion of Deltaproteobacteria, and corresponding increases in Fe-reduction and As mobilization (Islam et al., 2004; Lear et al., 2007; Rowland et al., 2007), as well as bacterial sulfate reduction (Héry et al., 2010). These microcosm results indicate that patterns in bacterial community composition are related to changes in As cycling in groundwater environments. However, questions remain about the types of microorganisms found in ambient conditions in the environment, and how their distribution varies with native geochemical conditions.

Thus, the goal of this work was to advance our understanding of microbial communities in As-rich groundwater sediments by combining high-throughput gene sequencing methods with environmental chemistry and statistical analysis. We were especially interested in the investigation of relationships between environmental chemistry and microbial community structure at the level of the entire aquifer since previous research at our study site has shown that groundwater arsenic increases with aquifer depth and location along the flowpath (Radloff et al., 2008; Mladenov et al.,
2010), and that dissolved organic matter chemistry changes with depth (Mladenov et al., 2010). We used the natural environmental gradients created by the groundwater flowpath and depth within the aquifer to demonstrate that patterns in bacterial community composition are correlated to sediment chemistry across a groundwater As concentration gradient in a GBD aquifer. The results from this work show that bacterial community structure is significantly different between separate locations in the groundwater aquifer. In addition, we demonstrate that variations in sediment grain size, as well as sediment $\mathrm{C}, \mathrm{Mn}$, and Fe concentrations correspond to variations in bacterial community structure.

\section{MATERIALS AND METHODS SITE DESCRIPTION}

This research was conducted at Site K (Radloff et al., 2008) in Araihazar, Bangladesh, approximately $30 \mathrm{~km}$ northeast of Dhaka $\left(23^{\circ}\right.$ $47^{\prime} 34^{\prime \prime} \mathrm{N}, 90^{\circ} 37^{\prime} 48^{\prime \prime} \mathrm{E}$ ). The regional climate is monsoonal, and receives more than $50 \%$ of the annual precipitation (average of $2354 \mathrm{~mm}$ ) between June and September (Immerzeel, 2008). Consequently, like similar sites in Araihazar (Stute et al., 2007), stream and groundwater levels at Site K vary seasonally and peak during July and August when most of the study site is flooded. Site K is located in a rural area within the floodplain of the Old Brahmaputra River, an abandoned river channel that has been filled through sedimentation and reduced to a small stream (Figure 1). Previous research at Site K has extensively characterized the hydrology and groundwater geochemistry (Radloff et al., 2008; Radloff, 2010). Like elsewhere in the GBD, shallow groundwater As concentrations are spatially variable, and can exceed $400 \mu \mathrm{g} / \mathrm{l}$ (Radloff et al., 2008). We examined groundwater and sediment samples from three monitoring nests along a groundwater flowpath at the study site. Well nest K240 is located $240 \mathrm{~m}$ from the river within a village, whereas well nests $\mathrm{K} 150$ and $\mathrm{K} 60$, located $150 \mathrm{~m}$, and $60 \mathrm{~m}$ from the river respectively, are located within cultivated rice fields. Based on groundwater age estimates, the mean direction of groundwater flow at the study site is from the village to the Old Brahmaputra River (Radloff, 2010). Thus, K240 is located near the beginning of the groundwater flowpath, K150 is located in the middle, and $\mathrm{K} 60$ is located at the end of the flowpath, directly upgradient of the river (Figure 1). During the wet season (approximately May-October), all three well nests at Site K are completely saturated due to groundwater table rise, with the exception of depths between 0 and $0.5 \mathrm{~m}$ within the village. In February, at the height of the dry season (Stute et al., 2007), depths between 0 and $3 \mathrm{~m}$ below the ground surface are unsaturated at all sampling locations at Site K.

The groundwater chemistry at Site $\mathrm{K}$ changes with location along the flowpath and depth within the aquifer (Radloff, 2010). Like other sites in Araihazar (Dhar et al., 2008), there are not marked seasonal changes in groundwater As concentrations (Radloff, 2010). Dissolved groundwater Fe and As concentrations are lowest at shallow depths at K240, and generally increase with depth at each well location (Radloff, 2010). In addition, groundwater As concentrations increase along the groundwater flowpath, and peak at $\mathrm{K} 60$ at $15 \mathrm{~m}(429 \mu \mathrm{g} / \mathrm{l})$. Groundwater Mn, by contrast, does not show patterns with depth or position along the flowpath (Radloff, 2010). 


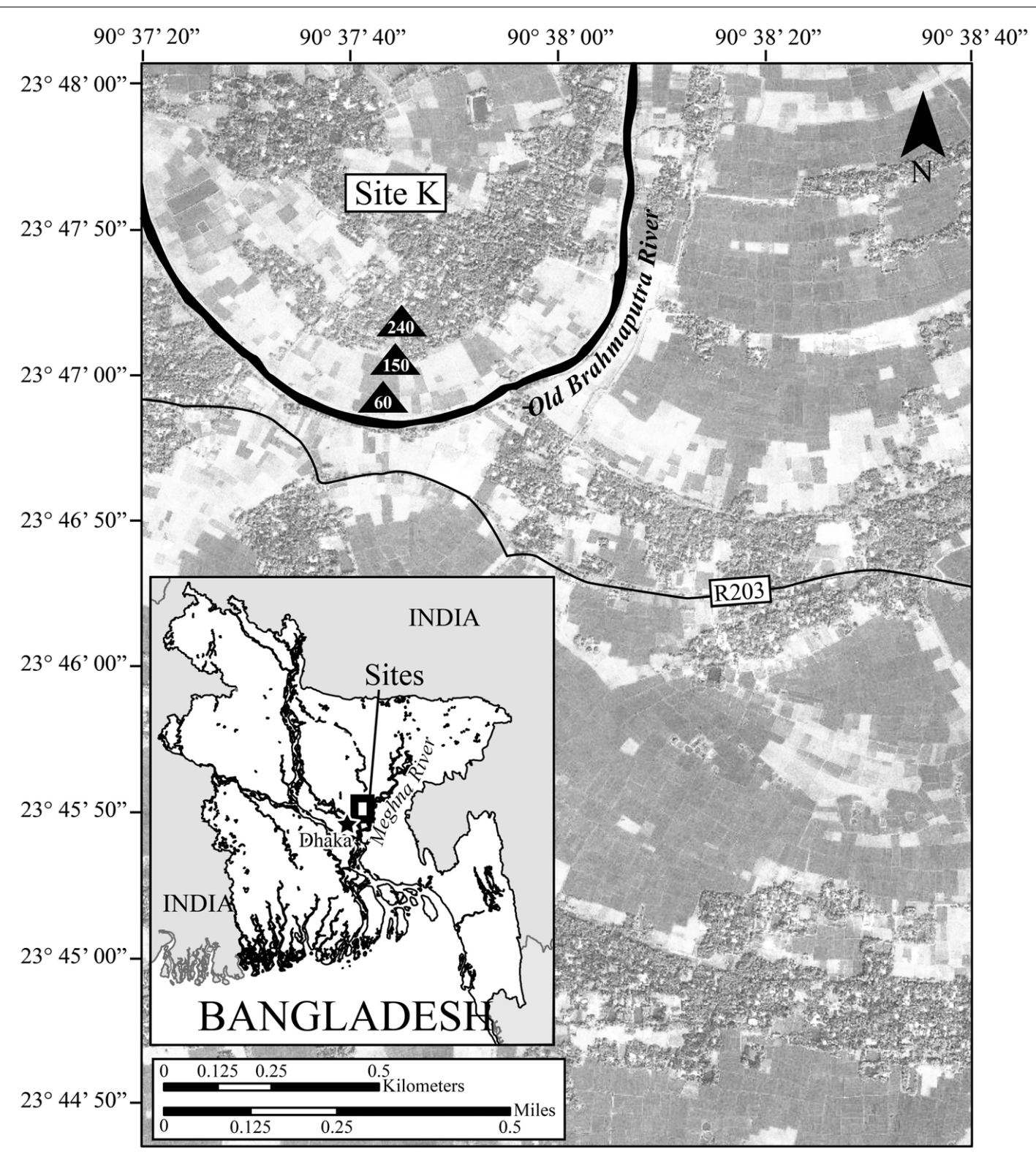

FIGURE 1 |The study area, Site K, in Araihazar, Bangladesh.

\section{SAMPLE COLLECTION AND PREPARATION}

We used the natural environmental gradients created by the groundwater flowpath and depth within the aquifer to examine the relationship between sediment chemistry and bacterial community composition. We collected sediment cores from three different sites within the aquifer, K240, K150, and K60 (Figure 1), adjacent to the monitoring well nests in July 2008. At each location we collected cores from seven aquifer depths: 1.52, 3.05, 4.57, 6.10, $7.62,10.67$, and $15.24 \mathrm{~m}$. We rinsed the sediment core liners with $100 \%$ ethanol prior to placing them in the coring device in order to minimize contamination. Also, we excised the top and bottom of each core with an ethanol-sterilized saw to remove sample that had contact with drilling fluids. We preserved the sediment cores in airtight mylar bags with oxygen-absorbing packets and placed them on ice in the field for approximately $4 \mathrm{~h}$; thereafter the cores were stored at $-80^{\circ} \mathrm{C}$. In the laboratory we opened each sediment core with a sterilized dremel tool, placed the sediment in a sterile bag, and then homogenized the sediment by hand from the 21 different cores (seven depths at three sites). During sieving, we did not observe plant roots or invertebrates such as worms.

\section{SEDIMENT CHEMICAL AND GRAIN SIZE ANALYSES}

We measured $\mathrm{pH}$ with an Accumet ${ }^{\circledR} \mathrm{AB} 15 \mathrm{pH}$ meter (Fisher Scientific, Inc., Waltham, MA, USA) in each of the homogenized sediment core samples after adding $1 \mathrm{~g}$ of the wet sediment to $1 \mathrm{ml}$ of de-ionized water (Carter, 1993). In order to quantify the percentage of $\mathrm{C}$ and nitrogen $(\mathrm{N})$ in each sample we first dried $5 \mathrm{~g}$ of homogenized sediment at $70^{\circ} \mathrm{C}$ for $48 \mathrm{~h}$; dried sediments were then 
ground to a fine powder (Cleveland et al., 2006). We used a Thermo Scientific FlashEA 1112 Elemental Analyzer (Thermo Fisher Scientific, Inc., $)$ with high temperature $\left(950^{\circ} \mathrm{C}\right)$ dry combustion to measure the percentage $\mathrm{C}$ and $\mathrm{N}$ in each sample (Matejovic, 1997). We estimated soil moisture in sediment samples by dividing the difference between the mass of the wet sediment and the mass of dried sediment by the mass of the wet sediment. The Laboratory for Environmental and Geological Studies (LEGS) at the University of Colorado (http://www.colorado.edu/geolsci/legs/indexa.html) conducted the analysis for determining the concentrations of $\mathrm{Mn}$, As, and Fe in each oven-dried, homogenized sediment sample. Sediment concentrations of $\mathrm{Mn}, \mathrm{As}$, and Fe were determined using a protocol modified from Farrell et al. (1980). Briefly, $5 \mathrm{ml}$ of a 7:3 mixture of hydrochloric acid and hydrofluoric acid and $2 \mathrm{ml}$ of nitric acid were added to sediment samples in digestion tubes. Tubes were then heated to $95^{\circ} \mathrm{C}$ in a digestion block for $2 \mathrm{~h}$. Next, samples were cooled and the volume of each sample was increased to $50 \mathrm{ml}$ with a $1.5 \%$ by weight boric acid solution. Samples were reheated to $95^{\circ} \mathrm{C}$ for about $15 \mathrm{~min}$, and then cooled to room temperature again. Metals concentrations were analyzed in the cooled solutions on a SCIEX inductively coupled plasma mass spectrometer, (Elan DRC-e, Perkin Elmer, Waltham, MA, USA) using an Indium internal standard.

We used a second set of aquifer sediment samples collected at $\mathrm{K} 240, \mathrm{~K} 150$, and $\mathrm{K} 60$ from depths between 1 and $16 \mathrm{~m}$ to investigate grain size. We used a modification of the USGS East Coast Sediment Analysis Procedures protocol for this analysis (Poppe et al., 2000). Sediments were freeze-dried for $48-72 \mathrm{~h}$ and then oven-dried at $60^{\circ} \mathrm{C}$ for $48 \mathrm{~h}$. In order to disaggregate the sediment, we suspended samples in distilled water for $24 \mathrm{~h}$. Then we passed each wet sub-sample serially through 150 and $63 \mu \mathrm{m}$ sieves. Sediment fractions were dried and weighed and grain size distributions were reported as percentage sand (i.e., greater than $150 \mu \mathrm{m}$ in diameter), silty-sand (between 150 and $63 \mu \mathrm{m}$ in diameter), and silt ( $63 \mu \mathrm{m}$ in diameter and smaller; Wentworth, 1922). In the statistical analyses we included data from only one grain size class, percentage silt, since percentage sand, percentage silty-sand, and percentage silt were strongly autocorrelated.

\section{PHYLOGENETIC DATA ANALYSIS}

DNA was extracted from homogenized sediment samples using the Mo Bio PowerSoil ${ }^{\mathrm{TM}}$ DNA Isolation Kit following the manufacturer's suggested protocol (Mo Bio Laboratories, Inc., Carlsbad, CA, USA). We PCR-amplified bacterial 16S rRNA genes from the genomic DNA of the 21 sediment samples for pyrosequencing (Margulies et al., 2005) analysis. We used a universal bacterial primer set described in Hamady et al. (2008) that included the highly conserved bacterial primers $27 \mathrm{~F}$ ( $5^{\prime}$-GCC TTGCCAGCCCGCTCAGTCAGAGTTTGATCCTGGCTCAG-3') and 338R, with a unique, error-correcting barcode that identifies the PCR product in each sample (5'-GCCTCCCTCGC GCCATCAGNNNNNNNNCATGCTGCCTCCCGTAGGAGT-3'; Fierer et al., 2008). Each reaction contained $3 \mu l$ of genomic DNA, $30 \mu \mathrm{M}$ (final concentrations) forward and reverse primers, and $22.5 \mu \mathrm{l}$ of Platinum SuperMix (Invitrogen, Carlsbad, CA, USA). Reaction conditions were performed as described by Fierer et al. (2008). We performed PCRs for each of the 21 samples in triplicate, and then pooled the products from each sample for downstream processing. No template controls were included to ensure that sample DNA was not contaminated with foreign DNA. PCR products were cleaned with the Mo Bio UltraCleanhtp PCR Clean-up Kit (Mo Bio Laboratories, Inc.,) according to the manufacturer's recommended protocol, and then pooled in equal concentrations. The University of South Carolina Environmental Genomics Core Facility performed the sequencing of our 16S rRNA gene amplicons on a Roche FLX 454 pyrosequencing machine.

First, we used QIIME (Caporaso et al., 2010a) to apply a sequence quality filter to the original $16 \mathrm{~S}$ rRNA gene sequence dataset based on the sequence quality log file. This quality filter eliminated sequences that were shorter than 200 nucleotides in length, in addition to those with one or more ambiguous bases, and/or had received a quality score of less than 25 . After this sequence quality filter, pyrosequencing yielded 31,517 quality short-read (average length of 231 nucleotides) 16S rRNA gene sequences total, and an average of 1500 sequences per sample (with a SD of 189). We used QIIME to conduct all of the following phylogenetic analyses of the 16S rRNA sequences (Caporaso et al., 2010a). We defined bacterial operational taxonomic units (OTUs) at $97 \%$ identity with the uclust (Edgar, 2010) and the cd-hit algorithm (Li and Godzik, 2006). As a source for comparison, we also defined bacterial OTUs at 90, 95, and 99\% identity with the cd-hit algorithm. We conducted all of the subsequently described analyses on each of these OTU tables in order to identify any discrepancies based on the OTU definition and patterns between bacterial community structure and chemistry (five tables total). Next, we filtered our dataset to eliminate OTUs represented by only one $16 \mathrm{~S}$ rRNA gene sequence (singletons), as well as OTUs present in only one sample (Zhou et al., 2011). The number of sequences present in each sample after applying filtering is included as Table A1 in Appendix. Then, we aligned the 16S rRNA gene sequences using the PyNAST alignment algorithm (Caporaso et al., 2010b) with the Greengenes database (DeSantis et al., 2006). In QIIME, we used the RDP Classifier (Wang et al., 2007) to assign the taxonomic classification to each OTU using the Greengenes database (DeSantis et al., 2006). To create a phylogeny, we implemented the FastTree algorithm (Price et al., 2009). We performed rarefaction analysis, and calculated collector's curves (Schloss and Handelsman, 2004) for many different alpha diversity metrics including the Chaol richness estimator (Chao, 1984) and Shannon diversity index (Weaver and Shannon, 1949). To investigate patterns in beta diversity, we calculated the pairwise distances between bacterial communities with the UniFrac distance metric (Lozupone and Knight, 2005). Sequences and sediment chemistry parameters were deposited in the MG-RAST database (Meyer et al., 2008) under accession number qiime:130 according to MIMARKS standards (Yilmaz et al., 2011).

\section{STATISTICAL ANALYSIS}

We used univariate and multivariate statistical techniques in order to elucidate relationships between the natural gradients within the aquifer, such as depth and well location, and the environmental chemistry and the bacterial community. We applied log transformations to percentage sediment $\mathrm{C}$ concentration, and square-root 

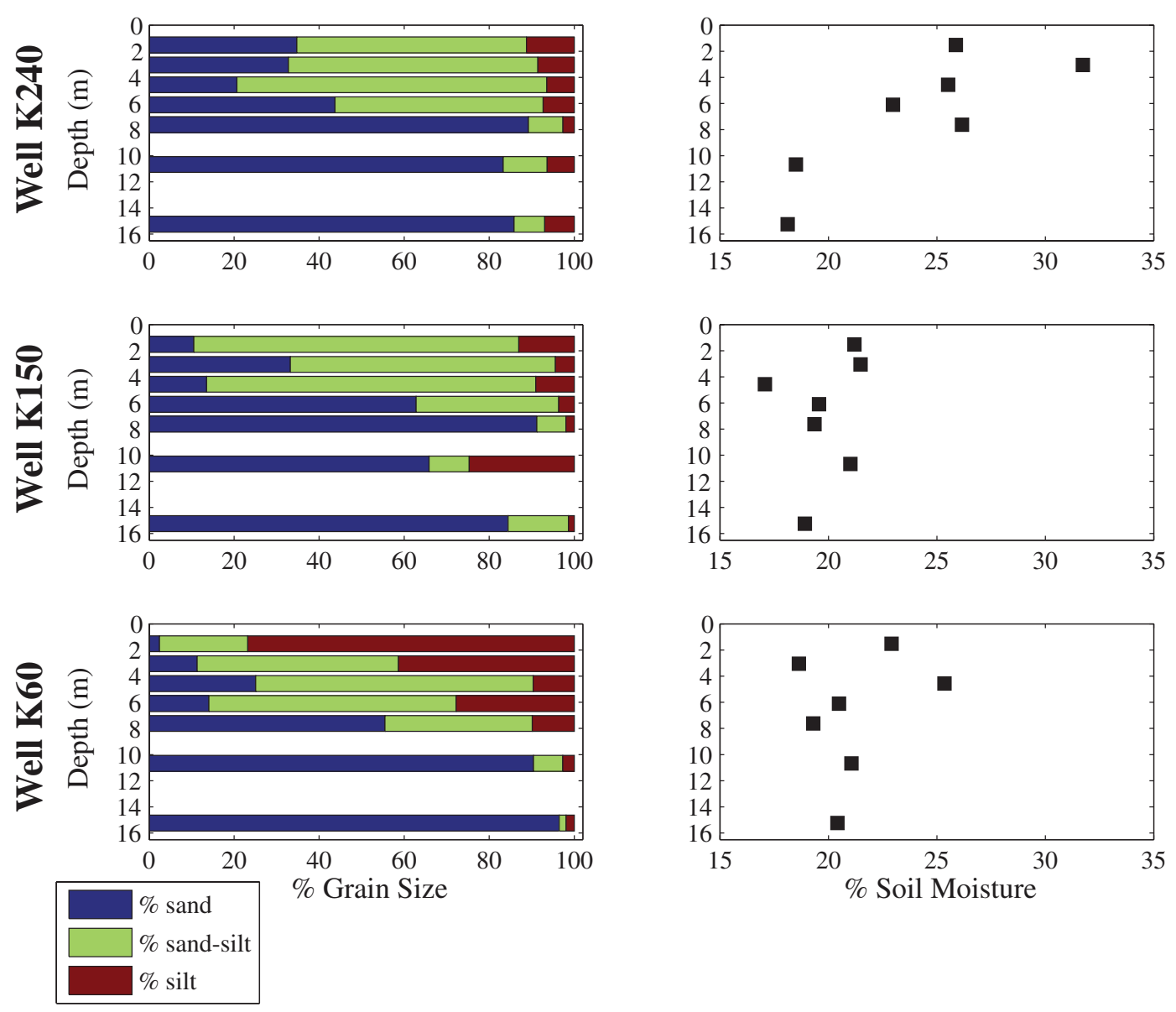

FIGURE 2 | Grain size distribution and soil moisture of sediments collected at depths of 1.52, 3.05, 4.57, 6.10, 7.62, 10.67, and 15.24 $\mathrm{m}$ at the three sampling locations along the groundwater flowpath at Site K.

transformations to sediment As and Fe concentrations because the raw data for these variables had non-normal distributions (Gotelli and Ellison, 2004). Then we performed linear correlation analyses using MATLAB ${ }^{\circledR}$ 7.9.0 (2009b) and the Pearson's correlation coefficient (Zar, 1999). We performed permutational multivariate ANOVA tests using the adonis function in the vegan package in $\mathrm{R}$ (Oksanen, 2007) in order to evaluate the role of depth and well location in structuring the bacterial community, as characterized by both unweighted UniFrac distances and proportions of bacterial taxa within the aquifer. Then, to examine the effects of sediment chemical parameters on structuring bacterial communities we performed Mantel tests on the bacterial community structure (i.e., the UniFrac distance matrix) and sediment chemistry data.

Next, we performed non-metric multidimensional scaling (NMDS), an unconstrained ordination technique, with the metaMDS function in the vegan package in $\mathrm{R}$ (Oksanen, 2007) on the unweighted UniFrac distance matrix in order to further examine patterns in bacterial community structure and environmental parameters. Then we used the envfit function in the vegan package in $\mathrm{R}$ (Oksanen, 2007) to fit vectors of the environmental parameters that were significantly related to bacterial community structure in the Mantel tests (square-root transformed Fe, $\log$ transformed $\% \mathrm{C}, \mathrm{Mn}$, and \% silt) to the NMDS ordination (Oksanen, 2007).

\section{RESULTS}

\section{SEDIMENT GRAIN SIZE AND CHEMISTRY}

The percentage of the sediment classified as sand ranged from 2.5 to 96 while the percentage silt ranged between 1.4 and 76.8 (Figure 2). The range in percentage silty-sand was from 1.6 to $77.4 \%$. The grain size distribution of the sediment samples varied based on the sample depth. Silt-sized grains predominated in the sediments collected at shallow depths $(<7 \mathrm{~m})$ within the aquifer, whereas sediments collected at deeper depths $(>7 \mathrm{~m})$ were primarily composed of sands. Sediment $\mathrm{C}$ ranged from 0.04 to $0.67 \%$ across all samples (Figure 3), while sediment $\mathrm{N}$ was at or below the detection limit of the analytical method (0.01\%) for 15 of the 21 samples. The samples were all circumneutral and $\mathrm{pH}$ ranged from 6.9 to 7.8. Sediment Mn concentrations ranged from $\sim 140$ to $1100 \mathrm{ppm}$, Fe from 10 to $50 \mathrm{ppt}$ and As from 5 to $39 \mathrm{ppm}$ (Figure 3). Sediment Mn concentration was the only chemical parameter that showed statistically significant differences between well sites, and was nearly twice as high at K60 than at K150 or K240 (ANOVA, $p<0.05$ ). Depth was significantly negatively correlated 


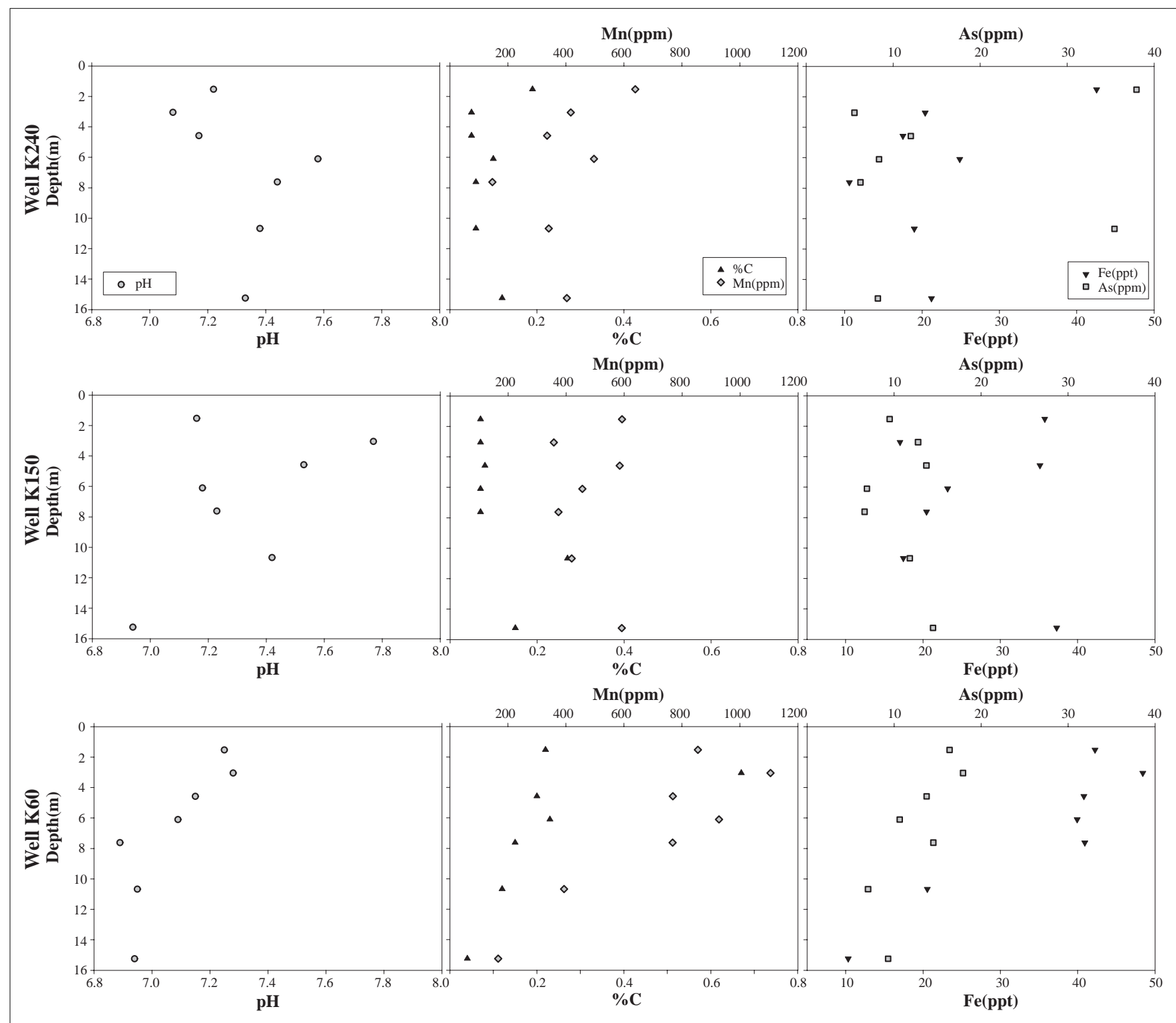

FIGURE 3 | Sediment chemistry at each sampling location along the groundwater flowpath.

to percentage silt and sediment $\mathrm{Mn}$ and Fe concentrations, whereas percent silt, $\mathrm{C}, \mathrm{Mn}$, and Fe were positively correlated with one another. Sediment $\mathrm{pH}$ was not correlated with any other chemical parameter measured in this study (Table 1).

\section{BACTERIAL COMMUNITY CHARACTERISTICS}

Rarefaction analysis demonstrated that there was a large variation in the total number of OTUs between the samples. Collector's curves for the Chaol richness estimator and Shannon diversity index showed that the overall diversity approached an asymptote in a majority of the samples (Figure A1 in Appendix), suggesting that the sequence coverage was sufficient to capture the diversity of the bacterial communities. Interestingly, it appeared that the alpha diversity of samples was related to the well location: the number of OTUs per sample was highest at Well K240 and lowest at well K60.
Although 35 phyla were present in the 21 samples, only four phyla comprised more than $5 \%$ of the community in every sample (Figure 4). Proteobacteria comprised approximately $28 \%$ of the average community across all samples, whereas Chloroflexi and Acidobacteria each comprised approximately $11 \%$ of the community. The proportion of Firmicutes was approximately $5 \%$, while other phyla represented much smaller proportions of the bacterial communities. Acidobacteria and Firmicutes were highly variable, with ranges in proportions of two orders of magnitude across all of the bacterial communities sampled, whereas the proportions of Chloroflexi and Proteobacteria varied by roughly one order of magnitude across the 21 samples. The sub-phyla Alphaproteobacteria, Betaproteobacteria, Deltaproteobacteria, and Gammaproteobacteria composed an average of $7,7,8$, and $5 \%$ of the overall bacterial community, respectively. 
Table 1 |The correlation coefficients ( $R$ values) for the Pearson's correlations that are presented in this table correspond to the pairwise correlations between individual environmental parameters or between environmental parameters and bacterial community beta diversity.

\begin{tabular}{|c|c|c|c|c|c|c|c|c|}
\hline $\begin{array}{l}\text { Correlation } \\
\text { Coefficients }(R)\end{array}$ & $\%$ Soil moisture & $\mathrm{pH}$ & $\log (\% \mathrm{C})$ & Mn (ppm) & $\sqrt{ }$ As (ppm) & $\sqrt{ } \mathrm{Fe}(\mathrm{ppm})$ & $\%$ Silt & UniFrac \\
\hline \% Soil moisture & & -0.05 (NS) & -0.21 (NS) & -0.17 (NS) & -0.13 (NS) & -0.16 (NS) & -0.01 (NS) & 0.003 (NS) \\
\hline $\log (\% \mathrm{C})$ & & & & $0.82(6 \mathrm{E}-6)$ & 0.32 (NS) & 0.71 (3E-4) & $0.62(0.002)$ & $0.39(0.005)$ \\
\hline Mn (ppm) & & & & & 0.32 (NS) & $0.93(6 \mathrm{E}-10)$ & $0.65(0.001)$ & $0.56(0.001)$ \\
\hline$\sqrt{ }$ As (ppm) & & & & & & 0.42 (NS) & 0.22 (NS) & -0.08 (NS) \\
\hline$\%$ Silt & & & & & & & & $0.44(0.007)$ \\
\hline UniFrac & & & & & & & & \\
\hline
\end{tabular}

Significance values (p-values) $\leq 0.05$ for the correlations are shown in parentheses; "NS" indicates non-significant correlations. We transformed data columns if the raw data did not follow a normal distribution. The transformation method we used is indicated in the row and column labels.

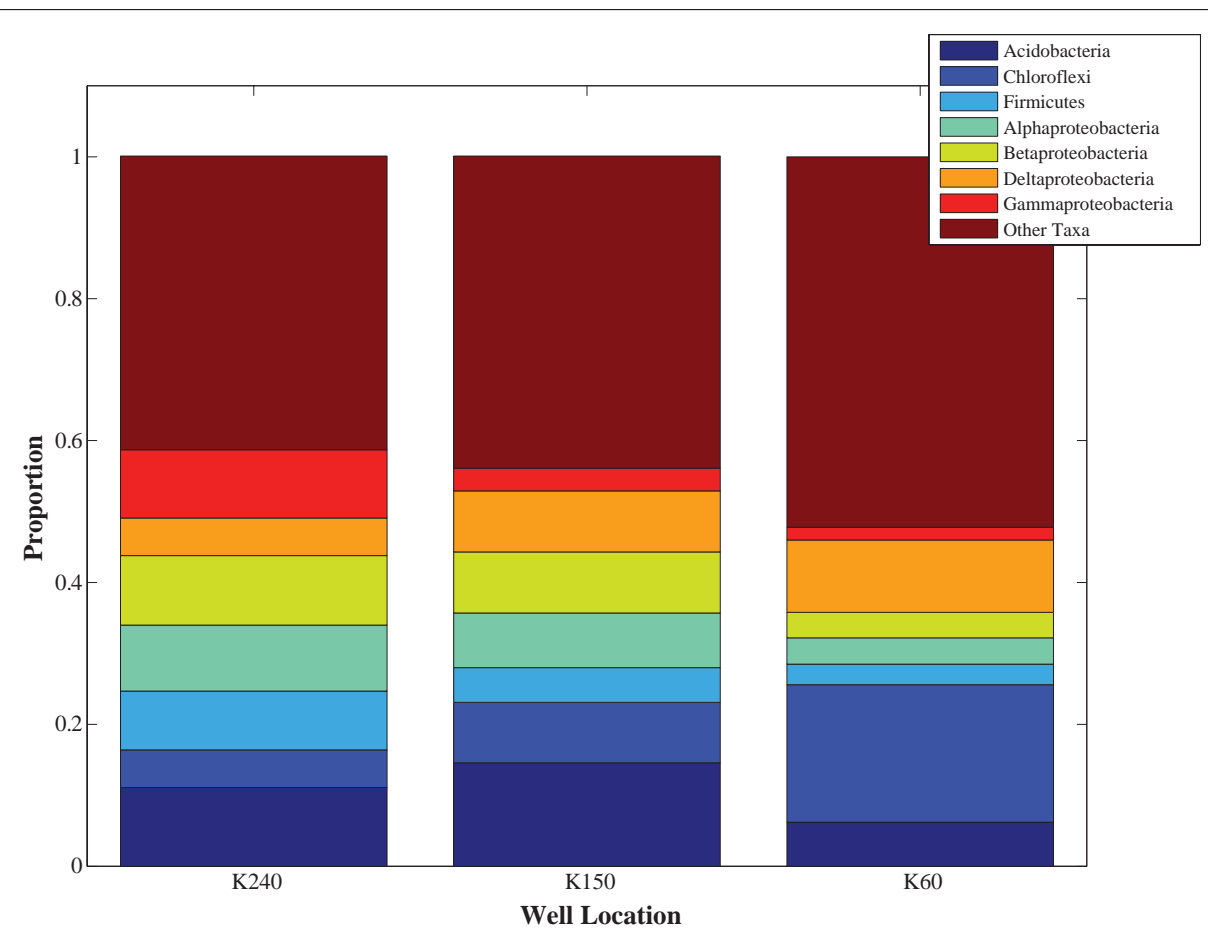

FIGURE 4 | The bacterial communities, as characterized by the UniFrac metric, are significantly distinct at the three well locations at our study site (PERMANOVA, $\boldsymbol{R}^{\mathbf{2}}=\mathbf{0 . 2 3} ; \boldsymbol{p} \leq \mathbf{0 . 0 0 1}$ ). The bar graphs show the relative abundances of dominant ( $>5 \%$ total abundance) bacterial taxa at the three well locations ( $n=7$ depths for each well) and in all wells combined. Although there are gradients in sediment texture and chemistry within the aquifer, only Mn was significantly different between wells (ANOVA, $p<0.05$ ).
Bacterial community composition was not significantly related to depth (Table 1). Instead, bacterial communities clustered by well site; a permutational multivariate ANOVA using the adonis function in the vegan package (Oksanen, 2007) revealed that well site accounted for a significant amount of the variation in community composition $\left(R^{2}=0.23\right.$; $\left.p<0.001\right)$. This relationship was significant $(p<0.05)$ for unweighted UniFrac distance matrices calculated from the pre-filtered and filtered datasets, and OTU tables calculated from different clustering methods (uclust and cd-hit) and different identity thresholds (90, 95, 97, and 99\%). Next, we investigated how the proportions of bacterial taxa contributed to these observed differences. The proportions of the most common (at least $5 \%$ of the total community) bacterial phyla and subphyla along the groundwater flowpath were significantly different between well locations $(p<0.05)$. Specifically, Deltaproteobacteria and Chloroflexi were found in higher relative abundance while Betaproteobacteria, Alphaproteobacteria, Gammaproteobacteria, and Firmicutes were in lower proportions in K60 (near the river) 


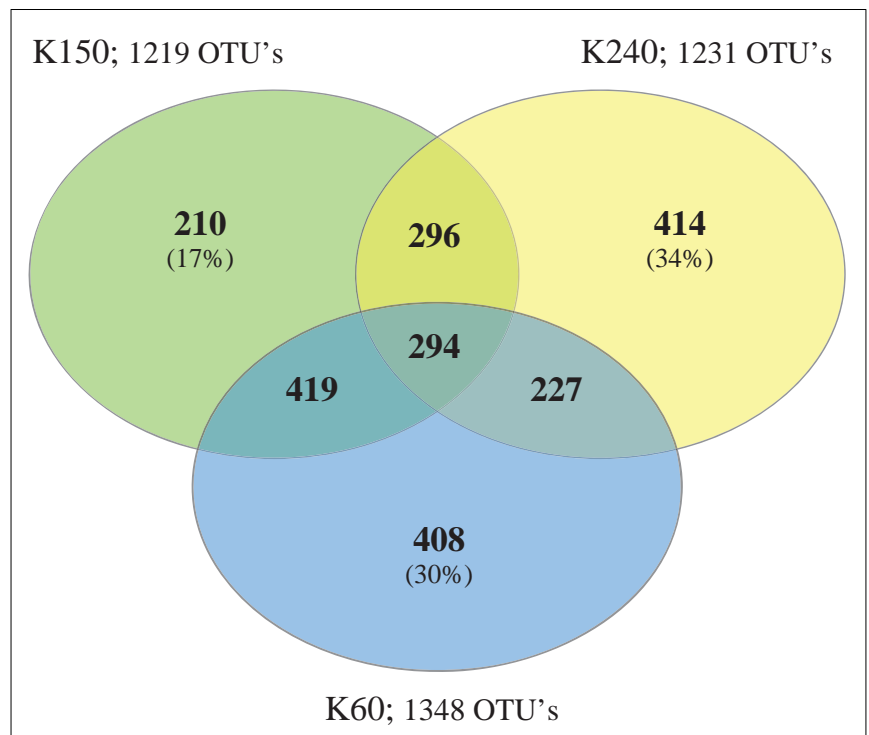

FIGURE 5 | As shown in the Venn diagram, a greater percentage of the OTUs present within the bacterial communities at well locations K240 (village) and K60 (river) were unique than at well K150 (mid flow path). In addition, K150 and K60 shared a greater percentage of OTUs (approximately $30 \%$ )

than K150 (middle of the flowpath) or K240 (village site, Figure 4). The proportion of Acidobacteria was highest at K150, and lowest at K60.

While roughly $30 \%$ of the OTUs in the bacterial communities at well $\mathrm{K} 240$ and well $\mathrm{K} 60$ were unique to that location, 17\% of the bacterial communities at K150 were comprised of unique OTUs (Figure 5). Bacteroidetes, Alphaproteobacteria, Acidobacteria, and Betaproteobacteria were the most frequently observed OTUs unique to well K240. Acidobacteria dominated the unique OTUs at K150. The OTUs that were unique to K60, the site closest to the river, were primarily Chloroflexi (30\%), and $50 \%$ of these Chloroflexi OTUs were classified in the Dehalococcoidetes class. All three of the well locations shared 294 OTUs; a majority of those OTUs (22\%) were classified within the Acidobacteria. The bacterial communities at K150 and K60 had the highest number of shared OTUs, which largely belonged to the Chloroflexi, Acidobacteria, and Deltaproteobacteria (comprising 16, 15, and $11 \%$ of the shared OTUs, respectively), the taxa that comprised the largest proportion of the 16S rRNA gene dataset at Site K. Only two taxonomic groups, Acidobacteria and Alphaproteobacteria, each comprised greater than $10 \%$ of the OTUs shared between K240 and K150. By contrast, the OTUs common to K240 and K60 were more taxonomically distributed: OTUs in the Betaproteobacteria, Alphaproteobacteria, Acidobacteria, Firmicutes, and Bacteroidetes each comprised greater than $10 \%$ of the shared OTUs between K240 and K60.

Mantel tests revealed that bacterial community composition, as characterized by the unweighted UniFrac metric (Lozupone and Knight, 2005), was significantly related to percentage silt, and sediment $\mathrm{C}, \mathrm{Mn}$, and Fe concentrations, but not sediment As or $\mathrm{pH}$ (Table 1). We performed the Mantel tests using unweighted

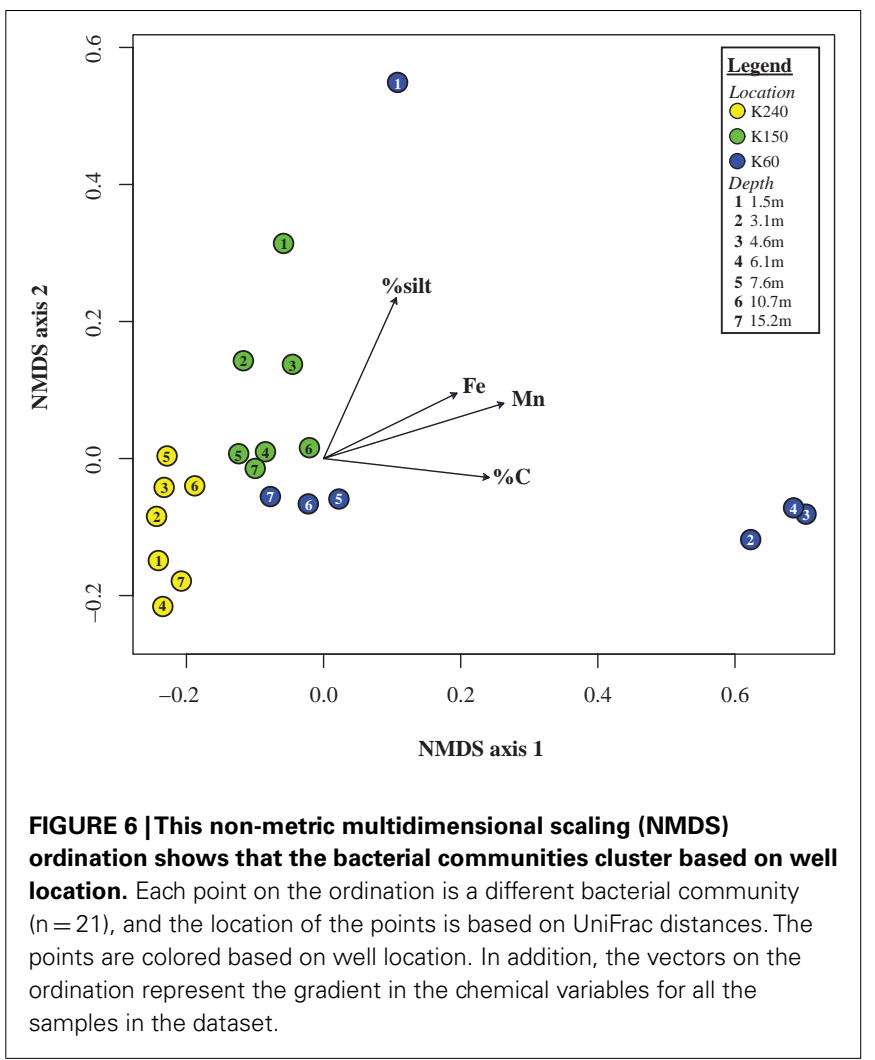

UniFrac distance matrices calculated from the pre-filtered and filtered datasets, as well as OTU tables calculated from different clustering methods (uclust and cd-hit), different identity thresholds (90, 95, 97, and 99\%), and different numbers of sequences per sample (Table A2 in Appendix). We found significant relationships between bacterial community structure and percentage silt, and sediment $\mathrm{C}, \mathrm{Mn}$, and Fe concentrations for each of these UniFrac distance matrices (Table A2 in Appendix) suggesting that the correlations observed are robust to issues related to sampling and OTU definition.

The results from the NMDS analysis, depicted in an ordination plot (Figure 6), demonstrate the relationship between bacterial community structure and environmental parameters. Each point on the ordination represents a bacterial community from a specific sample location and depth. The distances between samples (points) in the ordination indicate their level of similarity, as characterized by unweighted UniFrac distances. In order to investigate the validity of the NMDS ordination analysis we performed a stress plot, which showed that the UniFrac distances and the ordination distances were highly correlated $\left(R^{2}=0.98\right)$.

The NMDS ordination (Figure 6) demonstrates that bacterial communities, in general, cluster based on well location, which supports results from a permutational multivariate ANOVA. Also, the ordination shows that bacterial communities at K60 are more different from one another than at the other well locations. Whereas bacterial communities from the deepest depths at K60 cluster with communities from K150, bacterial communities at depths of $3.05 \mathrm{~m}, 4.57 \mathrm{~m}$, and $6.1 \mathrm{~m}$ at $\mathrm{K} 60$ form a distinct cluster between 0.6 and 0.7 on NMDS axis 1 (Figure 6). Similarly, the 
bacterial community from the shallowest depth at K60, $1.52 \mathrm{~m}$, is positioned at roughly 0.55 on NMDS axis 2, far from the other communities on the ordination (Figure 6). This suggests that the bacterial community structure at $1.52 \mathrm{~m}$ at $\mathrm{K} 60$ is distinct from bacterial communities at other locations at the study site. The direction and position of the environmental parameter vectors on the ordination, calculated with the envfit function in the vegan package (Oksanen, 2007), represent the gradient in each parameter (i.e., from lowest to highest concentration) as well as the strength of the correlation between the environmental parameter and the ordination (i.e., bacterial community structure, as characterized by UniFrac distances). The vectors provide a graphical representation to identify relationships between environmental gradients and patterns in bacterial community structure.

\section{DISCUSSION}

Bacterial community structure at Site $\mathrm{K}$ is significantly related to well location, grain size, and chemical differences in groundwater sediments, including percentage silt, and sediment C, Mn, and Fe concentrations (Table 1). Taxa such as Alphaproteobacteria, Betaproteobacteria, and Acidobacteria were more abundant at the village site (K240), in aquifer sediments with higher concentrations of sand and lower concentrations of $\mathrm{C}$ and metals. In addition, the OTUs that were present only at well location K240 belonged to these taxa. By contrast, OTUs classified as Deltaproteobacteria and Chloroflexi comprised a larger proportion of the communities in silty sediments with higher concentrations of $\mathrm{C}$, $\mathrm{Fe}$, and Mn (Figure 4). These results suggest that the considerable heterogeneity in sediment chemistry at Site K drives significant differences in bacterial community structure across the three well locations.

The dominant members (greater than $5 \%$ of the community) of the bacterial communities at Site K, Acidobacteria, Chloroflexi, Firmicutes, Alphaproteobacteria, Betaproteobacteria, Deltaproteobacteria, and Gammaproteobacteria (Figure 4), are abundant in many soil and sediment environments. Recent $16 \mathrm{~S}$ rRNA gene sequence-based analyses have found that Acidobacteria and Proteobacteria are the dominant members of soil bacterial communities across ecosystem types (Fierer et al., 2009). A global survey of 21 16S rRNA gene sequence libraries found that while Proteobacteria and Acidobacteria comprised roughly 40 and 20\% of the bacterial communities respectively, Chloroflexi and Firmicutes were also relatively abundant (greater than $5 \%$ of the community), in a range of soil environments (Janssen, 2006). Recent research shows that although these groups are dominant across soil types, the relative proportion of the bacterial community that each of these dominant groups comprises is influenced by factors such as $\mathrm{pH}$, depth within the soil profile, the degree of soil saturation, and anaerobiosis (Hansel et al., 2008; Fierer et al., 2009; Jones et al., 2009). In our study, we found that shifts in bacterial community structure were related to changes in the sediment grain size distribution and changes in sediment $\mathrm{C}, \mathrm{Mn}$, and Fe rather than soil moisture or depth (Table 1).

Our finding that bacterial community structure is significantly related to sediment grain size is supported by other research that has shown that sediment grain size influences microbial biomass and bacterial community structure (Sessitsch et al., 2001), and enzyme kinetics (Grandy et al., 2008). Silts typically have higher concentrations of organic matter (Sparks, 2003), especially aromatic carbon compounds and humic acids (Guggenberger et al., 1995), and metals (Thorne and Nickless, 1981; Murray et al., 1999). Sandy sediments, characterized by grain sizes larger than $150 \mu \mathrm{m}$, usually contain lower organic carbon and metal concentrations (Sparks, 2003). In the sandy sediments with high Si concentrations at Site K, phyla such as Firmicutes and Alphaproteobacteria are the dominant groups in the bacterial community. By contrast, Chloroflexi and Deltaproteobacteria were the dominant members of the bacterial community in silty sediments with high $\mathrm{C}$ and metal concentrations. Heavy metal concentrations have been shown to correlate with bacterial community structure and function in both soil and groundwater environments (Stefanowicz et al., 2008).

Deltaproteobacteria are abundant across different soil and sediment environments (Spain et al., 2009). There is evidence that Deltaproteobacteria are more abundant in anaerobic soils (Hansel et al., 2008), perhaps because members of Deltaproteobacteria can use a variety of electron acceptors. For example, organisms within the Geobacteraceae family can use labile $\mathrm{C}$ to reduce $\mathrm{Fe}, \mathrm{Mn}$, and HS (Lovley and Phillips, 1988; Lovley et al., 1996). There is ample evidence that Fe-, Mn-, and HS-reducing Deltaproteobacteria are prevalent in anaerobic freshwater sediments (Coates et al., 2002; Lovley et al., 2004), and previous research has documented that the relative abundance and diversity of members of Geobacteraceae corresponds to $\mathrm{Fe}$ and $\mathrm{Mn}$ concentrations in groundwater environments (Luna et al., 2009).

Although the overall community composition was not found to be correlated with sediment As (Table 1), it is important to note that there is a poor relationship between sediment and groundwater As concentrations in this environment (Radloff et al., 2008). However bacterial community structure is significantly correlated to sediment characteristics, such as percent silt, sediment $\mathrm{C}$, and sediment metal concentrations, which are related to groundwater As concentrations (van Geen et al., 2006b). Thus, the relationship between the proportion of Deltaproteobacteria in the bacterial community and percent silt and concentrations of $\mathrm{C}$ and $\mathrm{Fe}$ in the aquifer sediment may have important implications for understanding how the native microbial community influences groundwater As mobility at Site K. Fe-reducing Deltaproteobacteria could promote the mobilization of As by mediating the reductive dissolution of Fe-oxides, which results in the desorption of As from the Fe-oxide surface (McArthur et al., 2001; Jiang et al., 2009). In fact, results from GBD sediment microcosm experiments demonstrated that labile carbon additions promoted higher rates of $\mathrm{Fe}(\mathrm{III})$-reduction and As mobilization, as well as increases in the relative abundance of Deltaproteobacteria (Islam et al., 2004). Additional evidence from sediment microcosm experiments suggests that microbial Fe-reduction is enhanced by the presence of redox-active HS in aquifer sediments, which can shuttle electrons to $\mathrm{Fe}(\mathrm{III})$, promoting Fe-oxide reduction and As desorption (Mladenov et al., 2010). Thus, Fe-reducing and HS-reducing Deltaproteobacteria could play a significant role in groundwater As mobilization. 
Deltaproteobacteria could also influence groundwater As mobilization more directly. First, as mentioned above, although the overall community composition was not related to sediment As, it was correlated to the percent silt in the sediment. Fine-grained silts are less permeable than sands and often have higher dissolved As concentrations. Thus Deltaproteobacteria in the silty sediments at Site $\mathrm{K}$ may be more adapted to high groundwater As concentrations. Members of Deltaproteobacteria genera Desulfovibrio (Li and Krumholz, 2007), Desulfomicrobium (Macy et al., 2000), and Geobacter (Methe et al., 2003) are known to reduce $\mathrm{As}(\mathrm{V})$ to $\mathrm{As}(\mathrm{III})$ through a detoxification pathway encoded by the ars operon (Rosen et al., 1991). Groundwater As concentrations at Site $\mathrm{K}$ are highest at well $\mathrm{K} 60$ between 7 and $15 \mathrm{~m}$, and as a result these conditions may favor bacteria that can detoxify As. Thus, the potential for Deltaproteobacteria to mediate the As detoxification, Fe-reduction, Mn-reduction and HS-reduction pathways could explain their higher abundance at K60 (Figure 4).

Chloroflexi at Site $\mathrm{K}$ are also significantly more abundant in silty sediments with higher concentrations of sediment $\mathrm{C}, \mathrm{Fe}$, and Mn. Approximately 50\% of the Chloroflexi OTUs at Site K belonged to the halorespiring Dehalococcoidetes class, and these OTUs were only present in the C- and metal-rich silty sediments at well K60. Halorespiring Chloroflexi have also been discovered in other pristine freshwater environments (Loffler et al., 2000), and recent research suggests that halorespiring bacteria could also use other respiratory pathways including Se(VI)- reduction, As(V)-reduction, Fe(III)-reduction, Mn(IV)-reduction, as well as the oxidation and reduction of a model compound for quinonecontaining HS (Luijten et al., 2004). Also, two members of the Dehalococcoides genus have the As resistance gene, ars $C$, within their genome (Kube et al., 2005; Seshadri et al., 2005). Consequently, Chloroflexi may have an advantage at well K60 over other bacteria that do not have such adaptations to the local groundwater geochemical conditions.

Based on the phylogenetic affiliations of these taxa, it is possible that these results indicate a shift to more Fe-, Mn-, and humic substance-reducers in the silts with high $\mathrm{C}$ and metal concentrations (Lovley and Phillips, 1988; Lovley et al., 1996; Luijten et al., 2004). However, research is needed to further

\section{REFERENCES}

Caporaso, J. G., Kuczynski, J., Stombaugh, J., Bittinger, K., Bushman, F. D., Costello, E. K., Fierer, N., Peña, A. G., Goodrich, J. K., Gordon, J. I., Huttley, G. A., Kelley, S. T., Knights, D., Koenig, J. E., Ley, R. E., Lozupone, C. A., McDonald, D., Muegge, B. D., Pirrung, M., Reeder, J., Sevinsky, J. R., Turnbaugh, P. J., Walters, W. A., Widmann, J., Yatsunenko, T., Zaneveld, J., and Knight, R. (2010a). QIIME allows analysis of high-throughput community sequencing data. Nat. Methods 7, 335-336.

Caporaso, J. G., Bittinger, K., Bushman, F. D., DeSantis, T. Z., Andersen, G. L., and Knight, R. (2010b). PyNAST: a flexible tool for aligning sequences to a template alignment. Bioinformatics 26, 266-267.

Carter, M. R. (1993). Soil Sampling and Methods of Analysis. Boca Raton, FL: Lewis Publishers.

Chao, A. (1984). Nonparametric estimation of the number of classes in a population. Scand. Stat. Theory Appl. 11, 265-270.

Cleveland, C. C., Reed, S. C., and Townsend, A. R. (2006). Nutrient regulation of organic matter decomposition in a tropical rain forest. Ecology 87, 492-503.

Coates, J. D., Cole, K. A., Chakraborty, R., O'Connor, S. M., and Achenbach, L. A. (2002). Diversity and ubiquity

elucidate the specific roles of taxa such as Deltaproteobacteria and Chloroflexi in the groundwater environment at Site K. For example, our study suggests that sediment $\mathrm{C}$ is important in structuring bacterial communities and thus, further work on the source and chemical characteristics of the sediment $\mathrm{C}$ may provide insight into the dominant processes underlying the relationship between $\mathrm{C}$ and bacterial community composition. For example, if the $\mathrm{C}$ is serving largely as a nutrient source, we may conclude that observed community shifts are an example of the copiotrophic-oligotrophic continuum described by Fierer et al. (2007). By contrast, more recalcitrant, redox-active $\mathrm{C}$ sources such as HS may be important for electron shuttling that promotes Fe-reduction and As mobilization (Mladenov et al., 2010).

\section{CONCLUSION}

Results from this research have led to a more complete understanding of the bacterial community structure within GBD aquifer sediments. It is well-documented that sediment grain size, C, Mn, and Fe influence the mobility of groundwater arsenic, and it is intriguing that these constituents also structure the bacterial community. This work has also demonstrated the importance of deeper 16S rRNA gene sequencing in identifying environmentally relevant patterns in bacterial community structure across groundwater As gradients.

\section{ACKNOWLEDGMENTS}

This research was supported by grants from NSF (EAR 0738910 and 073888) and NIEHS (SRP 2 P42 ES10349). The authors would like to thank Dr. Rob Knight, Dr. Noah Fierer, as well as Douglas Wendel, Dr. Elizabeth Costello, and other members of the Knight and Fierer labs at the University of Colorado for assistance with sample preparation for pyrosequencing, and analysis of the 16S rRNA gene sequence data. We also thank Chris Washenberger, Sean O'Neill, and Peter Frey at INSTAAR at the University of Colorado for their help with soil analyses. Dr. Lee Stanish, Dr. William Wieder, Joseph Knelman, and Philip Taylor provided invaluable support with the statistical analyses presented in the manuscript, as well as insightful comments on previous versions of this manuscript.

of bacteria capable of utilizing humic substances as electron donors for anaerobic respiration. Appl. Environ. Microbiol. 68, 2445-2452.

Cummings, D. E., Caccavo, F., Fendorf, S., and Rosenzweig, R. F. (1999). Arsenic mobilization by the dissimilatory $\mathrm{Fe}$ (III)reducing bacterium Shewanella alga BrY. Environ. Sci. Technol. 33, 723-729.

DeSantis, T. Z., Hugenholtz, P., Larsen, N., Rojas, M., Brodie, E. L., Keller, K., Huber, T., Dalevi, D., Hu, P., and Andersen, G. L. (2006). Greengenes, a chimera-checked 16S rRNA gene database and workbench compatible with ARB. Appl. Environ. Microbiol. 72, 5069-5072.
Dhar, R. K., Zheng, Y., Saltikov, C. W., Radloff, K. A., Mailloux, B. J., Ahmed, K. M., and van Geen, A. (2011). Microbes enhance the mobility of arsenic in the Pleistocene aquifer sand from Bangladesh. Environ. Sci. Technol. 45, 2648-2654.

Dhar, R. K., Zheng, Y., Stute, M., van Geen, A., Cheng, Z., Shanewaz, M., Shamsudduha, M., Hoque, A., Rahman, M. W., and Ahmed, K. M. (2008). Temporal variability of groundwater chemistry in shallow and deep aquifers of Araihazar, Bangladesh. J. Contam. Hydrol. 99, 97-111.

Edgar, R. C. (2010). Search and clustering orders of magnitude faster than BLAST. Bioinformatics 26, 2460-2461. 
Farrell, R. F., Matthes, S. A., and Mackie, A. J. (1980). Simple, LowCost Method for the Dissolution of Metal and Mineral Samples in Plastic Pressure Vessels. Washington, DC: Department of the Interior, Bureau of Mines.

Fierer, N., Bradford, M. A., and Jackson, R. B. (2007). Toward an ecological classification of soil bacteria. Ecology 88, 1354-1364.

Fierer, N., Hamady, M., Lauber, C. L., and Knight, R. (2008). The influence of sex, handedness, and washing on the diversity of hand surface bacteria. Proc. Natl. Acad. Sci. U.S.A. 105, 17994-17999.

Fierer, N., Strickland, M. S., Liptzin, D., Bradford, M. A., and Cleveland, C. C. (2009). Global patterns in belowground communities. Ecol. Lett. 12, 1238-1249.

Gotelli, N. J., and Ellison, A. M. (2004). A Primer of Ecological Statistics. Sunderland, MA: Sinauer Associates, Inc.

Grandy, A. S., Sinsabaugh, R. L., Neff, J. C., Stursova, M., and Zak, D. R. (2008). Nitrogen deposition effects on soil organic matter chemistry are linked to variation in enzymes, ecosystems and size fractions. Biogeochemistry 91, 37-49.

Guggenberger, G., Zech, W., Haumaier, L., and Christensen, B. T. (1995). Land-use effects on the composition of organic matter in particlesize separates of soils: II. CPMAS and solution 13C NMR analysis. Eur. J. Soil Sci. 46, 147-158.

Hamady, M., Walker, J. J., Harris, J. K., Gold, N. J., and Knight, R. (2008). Error-correcting barcoded primers for pyrosequencing hundreds of samples in multiplex. Nat. Methods 5, 235-237.

Hansel, C. M., Fendorf, S., Jardine, P. M., and Francis, C. A. (2008). Changes in bacterial and archaeal community structure and functional diversity along a geochemically variable soil profile. Appl. Environ. Microbiol. 74, 1620-1633.

Héry, M., Van Dongen, B. E., Gill, F., Mondal, D., Vaughan, D. J., Pancost, R. D., Polya, D. A., and Lloyd, J. R. (2010). Arsenic release and attenuation in low organic carbon aquifer sediments from West Bengal. Geobiology 8, 155-168.

Immerzeel, W. (2008). Historical trends and future predictions of climate variability in the Brahmaputra basin. Int. J. Climatol. 28, 243-254.

Inskeep, W. P., McDermott, T. R., and Fendorf, S. E. (2002). "Arsenic
(V/III) cycling in soils and natural waters: chemical and microbiological processes," in Environmental Chemistry of Arsenic, ed. W. T. Frankenberger Jr. (New York, NY: Springer-Verlag), 183-215.

Islam, F. S., Gault, A. G., Boothman, C., Polya, D. A., Charnock, J. M., Chatterjee, D., and Lloyd, J. R. (2004). Role of metal-reducing bacteria in arsenic release from Bengal delta sediments. Nature 430, 68-71.

Janssen, P. H. (2006). Identifying the dominant soil bacterial taxa in libraries of $16 \mathrm{~S}$ rRNA and $16 \mathrm{~S}$ rRNA genes. Appl. Environ. Microbiol. 72, 1719-1728.

Jiang, J., Bauer, I., Paul, A., and Kappler, A. (2009). Arsenic redox changes by microbially and chemically formed semiquinone radicals and hydroquinones in a humic substance model quinone. Environ. Sci. Technol. 43, 3639-3645.

Jiang, J., and Kappler, A. (2008). Kinetics of microbial and chemical reduction of humic substances: implications for electron shuttling. Environ. Sci. Technol. 42, 3563-3569.

Jones, R. T., Robeson, M. S., Lauber, C. L., Hamady, M., Knight, R., and Fierer, N. (2009). A comprehensive survey of soil acidobacterial diversity using pyrosequencing and clone library analyses. ISME J. 3, 442-453.

Kappler, A., Benz, M., Schink, B., and Brune, A. (2004). Electron shuttling via humic acids in microbial iron (III) reduction in a freshwater sediment. FEMS Microbiol. Ecol. 47, 85-92.

Kirk, M. F., Holm, T. R., Park, J., Jin, Q., Sanford, R. A., Fouke, B. W., and Bethke, C. M. (2004). Bacterial sulfate reduction limits natural arsenic contamination in groundwater. Geology 32, 953-956.

Kube, M., Beck, A., Zinder, S. H., Kuhl, H., Reinhardt, R., and Adrian, L. (2005). Genome sequence of the chlorinated compound-respiring bacterium Dehalococcoides species strain CBDB1. Nat. Biotechnol. 23, 1269-1273.

Lear, G., Song, B., Gault, A. G., Polya, D. A., and Lloyd, J. R. (2007). Molecular analysis of arsenate-reducing bacteria within Cambodian sediments following amendment with acetate. Appl. Environ. Microbiol. 73, 1041-1048.

Li, W., and Godzik, A. (2006). Cd-hit: a fast program for clustering and comparing large sets of protein or nucleotide sequences. Bioinformatics 22, $1658-1659$.

Li, X., and Krumholz, L. R. (2007). Regulation of arsenate resistance in Desulfovibrio desulfuricans G20 by an arsRBCC operon and an arsC gene. J. Bacteriol. 189, 3705-3711.

Loffler, F. E., Sun, Q., Li, J., and Tiedje, J. M. (2000). 16S rRNA gene-based detection of tetrachloroethenedechlorinating Desulfuromonas and Dehalococcoides species. Appl. Environ. Microbiol. 66, 1369-1374.

Lovley, D. R., Coates, J. D., BluntHarris, E. L., Phillips, E. J. P., and Woodward, J. C. (1996). Humic substances as electron acceptors for microbial respiration. Nature 382 , 445-448.

Lovley, D. R., and Phillips, E. J. P. (1988). Novel mode of microbial energy metabolism: organic carbon oxidation coupled to dissimilatory reduction of iron or manganese. Appl. Environ. Microbiol. 54, 1472-1480.

Lovley, D. R., Holmes, D. E., and Nevin, K. P. (2004). Dissimilatory Fe(III) and $\mathrm{Mn}(\mathrm{IV})$ reduction. Adv. Microb. Physiol. 49, 219-286.

Lozupone, C., and Knight, R. (2005). UniFrac: a new phylogenetic method for comparing microbial communities. Appl. Environ. Microbiol. 71, 8228.

Luijten, M. L. G., Weelink, S. A., Godschalk, B., Langenhoff, A. A., Eekert, M. H., Schraa, G., and Stams, A. J. (2004). Anaerobic reduction and oxidation of quinone moieties and the reduction of oxidized metals by halorespiring and related organisms. FEMS Microbiol. Ecol. 49, 145-150.

Luna, G. M., Dell'Anno, A., Corinaldesi, C., Armeni, M., and Danovaro, R. (2009). Diversity and spatial distribution of metal-reducing bacterial assemblages in groundwaters of different redox conditions. Int. Microbiol. 12, 153-159.

Macy, J. M., Santini, J. M., Pauling, B. V., O'Neill, A. H., and Sly, L. I. (2000). Two new arsenate/sulfatereducing bacteria: mechanisms of arsenate reduction. Arch. Microbiol. 173, 49-57.

Margulies, M., Egholm, M., Altman, W. E., Attiya, S., Bader, J. S., Bemben, L. A., Berka, J., Braverman, M. S., Chen, Y. J., Chen, Z., Dewell, S. B., Du, L., Fierro, J. M., Gomes, X. V., Godwin, B. C., He, W., Helgesen, S., Ho, C. H., Irzyk, G. P., Jando, S. C., Alenquer, M. L., Jarvie, T. P., Jirage, K. B., Kim, J. B., Knight, J. R., Lanza, J. R., Leamon, J. H., Lefkowitz, S. M., Lei, M., Li, J.,
Lohman, K. L., Lu, H., Makhijani, V. B., McDade, K. E., McKenna, M. P. Myers, E. W., Nickerson, E., Nobile, J. R., Plant, R., Puc, B. P., Ronan, M. T., Roth, G. T., Sarkis, G. J., Simons, J. F., Simpson, J. W., Srinivasan, M., Tartaro, K. R., Tomasz, A., Vogt, K. A., Volkmer, G. A., Wang, S. H., Wang, Y., Weiner, M. P., Yu, P., Begley, R. F., and Rothberg, J. M. (2005). Genome sequencing in microfabricated high-density picolitre reactors. Nature 437, 376-380.

Matejovic, I. (1997). Determination of carbon and nitrogen in samples of various soils by the dry combustion. Commun. Soil Sci. Plant Anal. 28, 1499-1511.

McArthur, J. M., Banerjee, D. M., Hudson-Edwards, K. A., Mishra, R., Purohit, R., Ravenscroft, P., Cronin, A., Howarth, R. J., Chatterjee, A., Talukder, T., Lowry, D., Houghton, S., and Chadha, D. K. (2004). Natural organic matter in sedimentary basins and its relation to arsenic in anoxic ground water: the example of West Bengal and its worldwide implications. Appl. Geochem. 19, 1255-1293.

McArthur, J. M., Ravenscroft, P. Safiulla, S., and Thirlwall, M. F. (2001). Arsenic in groundwater: testing pollution mechanisms for sedimentary aquifers in Bangladesh. Water Resour. Res. 37, 109-117.

Methe, B. A., Nelson, K. E., Eisen, J. A. Paulsen, I. T., Nelson, W., Heidelberg, J. F., Wu, D., Wu, M., Ward, N., Beanan, M. J., Dodson, R. J., Madupu, R., Brinkac, L. M., Daugherty, S. C., DeBoy, R. T., Durkin, A. S., Gwinn, M., Kolonay, J. F., Sullivan, S. A., Haft, D. H., Selengut, J., Davidsen, T. M., Zafar, N., White, O., Tran, B., Romero, C., Forberger, H. A., Weidman, J., Khouri, H., Feldblyum, T. V., Utterback, T. R., Van Aken, S. E., Lovley, D. R., and Fraser, C. M. (2003). Genome of Geobacter sulfurreducens: metal reduction in subsurface environments. Science 302, 1967-1969.

Meyer, F., Paarmann, D., D’Souza, M., Olson, R., Glass, E. M., Kubal, M., Paczian, T., Rodriguez, A., Stevens, R., Wilke, A., Wilkening, J., and Edwards, R. A. (2008). The metagenomics RAST server - a public resource for the automatic phylogenetic and functional analysis of metagenomes. BMC Bioinformatics 9, 386-393. doi:10.1186/ 1471-2105-9-386

Mladenov, N., Zheng, Y., Miller, M. P., Nemergut, D. R., Legg, T., Simone, B., Hageman, C., Rahman, M. M., 
Ahmed, K. M., and McKnight, D. M. (2010). Dissolved organic matter sources and consequences for iron and arsenic mobilization in Bangladesh aquifers. Environ. Sci. Technol. 44, 123-128.

Mukhopadhyay, R., Rosen, B. P., Phung, L. T., and Silver, S. (2002). Microbial arsenic: from geocycles to genes and enzymes. FEMS Microbiol. Rev. 26, $311-325$.

Murray, K. S., Cauvet, D., Lybeer, M., and Thomas, J. C. (1999). Particle size and chemical control of heavy metals in bed sediment from the Rouge River, Southeast Michigan. Environ. Sci. Technol. 33, 987-992.

Neumann, R. B., Ashfaque, K. N., Badruzzaman, A. B. M., Ashraf Ali, M., Shoemaker, J. K., and Harvey, C. F. (2010). Anthropogenic influences on groundwater arsenic concentrations in Bangladesh. Nat. Geosci. 3, 46-52.

Newman, D., Beveridge, T., and Morel, F. (1997). Precipitation of arsenic trisulfide by Desulfotomaculum auripigmentum. Appl. Environ. Microbiol. 63, 2022-2028.

Oksanen, J. (2007). Multivariate Analysis of Ecological Communities in $R$ : Vegan Tutorial. Available at: http://cc.oulu.fi/jarioksa/opetus/ metodi/vegantutor.pdf

Polizzotto, M. L., Harvey, C. F, Sutton, S. R., and Fendorf, S. (2005). Processes conducive to the release and transport of arsenic into aquifers of Bangladesh. Proc. Natl. Acad. Sci. U.S.A. 102, 18819-18823.

Poppe, L. J., Eliason, A. H., Fredericks, J. J., Rendigs, R. R., Blackwood, D., and Polloni, C. (2000). USGS East-Coast Sediment Analysis: Procedures, Database, and Georeferenced Displays (U.S. Geological Survey Open-File Report No. 00-358). Reston, VA: U.S. Department of the Interior, U.S. Geological Survey.

Price, M. N., Dehal, P. S., and Arkin, A. P. (2009). FastTree: computing large minimum evolution trees with profiles instead of a distance matrix. Mol. Biol. Evol. 26, 1641-1650.

Radloff, K. (2010). Geochemical and Hydrologic Determinants of Arsenic Distribution in Sedimentary Aquifers in Bangladesh (Doctor of Philosophy). New York: Columbia University.

Radloff, K. A., Manning, A. R., Mailloux, B., Zheng, Y., Moshiur Rahman, M., Rezaul Huq, M., Ahmed, K. M., and van Geen, A. (2008). Considerations for conducting incubations to study the mechanisms of As release in reducing groundwater aquifers. Appl. Geochem. 23, 3224-3235.

Rittle, K. A., Drever, J. I., and Colberg, P. J. S. (1995). Precipitation of arsenic during bacterial sulfate reduction. Geomicrobiol. J. 13, 1-11.

Rosen, B. P., Weigel, U., Monticello, R. A., and Edwards, B. P. (1991). Molecular analysis of an anion pump: purification of the ArsC protein. Arch. Biochem. Biophys. 284, 381-385.

Rowland, H. A. L., Pederick, R. L., Polya, D. A., Pancost, R. D., Dongen, B. E. V., Gault, A. G., Vaughan, D. J., Bryant, C., Anderson, B., and Lloyd, J. R. (2007). The control of organic matter on microbially mediated iron reduction and arsenic release in shallow alluvial aquifers, Cambodia. Geobiology 5, 281-292.

Saalfield, S. L., and Bostick, B. C. (2009). Changes in iron, sulfur, and arsenic speciation associated with bacterial sulfate reduction in ferrihydrite-rich systems. Environ. Sci. Technol. 43, 8787-8793.

Saltikov, C. W., and Newman, D. K. (2003). Genetic identification of a respiratory arsenate reductase. Proc. Natl. Acad. Sci. U.S.A. 100, 10983-10988.

Schloss, P. D., and Handelsman, J. (2004). Status of the microbial census. Microbiol. Mol. Biol. Rev. 68, 686-691.

Seshadri, R., Adrian, L., Fouts, D. E., Eisen, J. A., Phillippy, A. M., Methe, B. A., Ward, N. L., Deboy, R. T., Khouri, H. M., Kolonay, J. F., Dodson, R. J., Daugherty, S. C., Brinkac, L. M., Sullivan, S. A., Madupu, R., Nelson, K. E., Kang, K. H., Impraim, M, Tran, K, Robinson, J. M., Forberger, H. A., Fraser, C. M., Zinder, S. H., and Heidelberg, J. F. (2005). Genome sequence of the PCE-dechlorinating bacterium Dehalococcoides ethenogenes. Science 307, 105-108.

Sessitsch, A., Weilharter, A., Gerzabek, M. H., Kirchmann, H., and Kandeler, E. (2001). Microbial population structures in soil particle size fractions of a long-term fertilizer field experiment. Appl. Environ. Microbiol. 67, 4215-4224.

Spain, A. M., Krumholz, L. R., and Elshahed, M. S. (2009). Abundance, composition, diversity and novelty of soil Proteobacteria. ISME J. 3, 992-1000.

Sparks, D. L. (2003). Environmental Soil Chemistry. San Diego, CA: Academic Press.
Stefanowicz, A. M., Niklinska, M. and Laskowski, R. (2008). Metals affect soil bacterial and fungal functional diversity differently. Environ. Toxicol. Chem. 27, 591-598.

Stute, M., Zheng, Y., Schlosser, P., Horneman, A., Dhar, R., Datta, S., Hoque, M., Seddique, A. A., Shamsudduha, M., Ahmed, K. M., and van Geen, A. (2007). Hydrological control of As concentrations in Bangladesh groundwater. Water Resour. Res. 43 , W09417.

Sun, Y., Polishchuk, E. A., Radoja, U., and Cullen, W. R. (2004). Identification and quantification of arsC genes in environmental samples by using real-time PCR. J. Microbiol. Methods 58, 335-349.

Thorne, L. T., and Nickless, G. (1981). The relation between heavy metals and particle size fractions within the severn estuary (U.K.) inter-tidal sediments. Sci. Total Environ. 19, 207-213.

Tufano, K. J., and Fendorf, S. (2008). Confounding impacts of iron reduction on arsenic retention. Environ. Sci. Technol. 42, 4777-4783.

van Geen, A., Aziz, Z., Horneman, A. Weinman, B., Dhar, R. K., Zheng, Y., Goodbred, S., Versteeg, R., Seddique, A. A., Hoque, M. A., and Ahmed, K. M. (2006a). Preliminary evidence of a link between surface soil properties and the arsenic content of shallow groundwater in Bangladesh. J. Geochem. Explor. 88, 157-161.

van Geen, A., Zheng, Y., Cheng, Z. Aziz, Z., Horneman, A., Dhar, R. K., Mailloux, B., Stute, M., Weinman, B., Goodbred, S., Seddique, A A., Hoque, M. A., and Ahmed, K. M. (2006b). A transect of groundwater and sediment properties in Araihazar, Bangladesh: further evidence of decoupling between As and Fe mobilization. Chem. Geol. 228, 85-96.

van Geen, A., Zheng, Y., Versteeg, R. Stute, M., Horneman, A., Dhar, R. K., Steckler, M., Gelman, A., Small, C., Ahsan, H., Graziano, J., Hussein, I., and Ahmed, K. M. (2003). Spatial variability of arsenic in 6000 tube wells in a $25 \mathrm{~km} 2$ area of Bangladesh. Water Resour. Res. 39, 1140-1156.

Wang, Q., Garrity, G. M., Tiedje, J. M., and Cole, J. R. (2007). Naive bayesian classifier for rapid assignment of rRNA sequences into the new bacterial taxonomy. Appl. Environ. Microbiol. 73, 5261-5267.
Weaver, W., and Shannon, C. E. (1949). Recent Contributions to the Mathematical Theory of Communication. Urbana, IL: University of Illinois Press.

Wentworth, C. K. (1922). A scale of grade and class terms for clastic sediments. J. Geol. 30, 377-392.

Winkel, L., Berg, M., Amini, M., Hug, S. J., and Johnson, C. A. (2008). Predicting groundwater arsenic contamination in Southeast Asia from surface parameters. Nat. Geosci. 1, 536-542.

Yilmaz, P., Kottmann, R., Field, D., Knight, R., Cole, J. R., AmaralZettler, L., Gilbert, J. A., KarschMizrachi, I., Johnston, A., Cochrane, G., Vaughan, R., Hunter, C., Park, J., Morrison, N., Rocca-Serra, P., Sterk, P., Arumugam, M., Bailey, M., Baumgartner, L., Birren, B. W. Blaser, M. J., Bonazzi, V., Booth, T., Bork, P., Bushman, F. D., Buttigieg, P. L., Chain, P. S., Charlson, E., Costello, E. K., Huot-Creasy, H., Dawyndt, P., DeSantis, T., Fierer, N., Fuhrman, J. A., Gallery, R. E., Gevers, D., Gibbs, R. A., San Gil, I., Gonzalez, A., Gordon, J. I., Guralnick, R., Hankeln, W., Highlander, S., Hugenholtz, P., Jansson, J., Kau, A. L., Kelley, S. T., Kennedy, J., Knights, D., Koren, O., Kuczynski, J., Kyrpides, N., Larsen, R., Lauber, C. L., Legg, T., Ley, R. E., Lozupone, C. A., Ludwig, W., Lyons, D., Maguire, E., Methé, B. A., Meyer, F., Muegge, B., Nakielny, S., Nelson, K. E., Nemergut, D., Neufeld, J. D., Newbold, L. K., Oliver, A. E., Pace, N. R., Palanisamy, G., Peplies, J., Petrosino, J., Proctor, L., Pruesse, E., Quast, C., Raes, J., Ratnasingham, S., Ravel, J., Relman, D. A., Assunta-Sansone, S., Schloss, P. D., Schriml, L., Sinha, R., Smith, M. I., Sodergren, E., Spo, A., Stombaugh, J., Tiedje, J. M., Ward, D. V., Weinstock, G. M., Wendel, D., White, O., Whiteley, A., Wilke, A., Wortman, J. R., Yatsunenko, T., and Glöckner, F. O. (2011). Minimum information about a marker gene sequence (MIMARKS) and minimum information about any $(\mathrm{x})$ sequence (MIxS) specifications. Nat. Biotechnol. 29, 415-420.

Zar, J. H. (1999). Biostatistical Analysis, 4th Edn. Upper Saddle River, NJ: Prentice Hall.

Zheng, Y., Stute, M., van Geen, A., Gavrieli, I., Dhar, R. K., Simpson, H. J., Schlosser, P., and Ahmed, K. M. (2004). Redox control of arsenic mobilization in Bangladesh groundwater. Appl. Geochem. 19, 201-214. 
Zhou, J., Wu, L., Deng, Y., Zhi, X., Jiang, Y.-H., Tu, Q., Xie, J., Van Nostrand, J. D., He, Z., and Yang, Y. (2011). Reproducibility and quantitation of amplicon sequencing-based detection. ISME J. 5, 1303-1313.

Conflict of Interest Statement: The authors declare that the research was conducted in the absence of any commercial or financial relationships that could be construed as a potential conflict of interest.

Received: 08 December 2011; paper pending published: 27 December 2011; accepted: 17 February 2012; published online: 23 March 2012.

Citation: Legg TM, Zheng Y, Simone $B$, Radloff KA, Mladenov N, González
A, Knights D, Siu HC, Rahman MM, Ahmed KM, McKnight DM and Nemergut DR (2012) Carbon, metals, and grain size correlate with bacterial community structure in sediments of a high arsenic aquifer. Front. Microbio. 3:82. doi: 10.3389/fmicb.2012.00082 This article was submitted to Frontiers in Terrestrial Microbiology, a specialty of Frontiers in Microbiology.
Copyright $\odot 2012$ Legg, Zheng, Simone, Radloff, Mladenov, González, Knights, Siu, Rahman, Ahmed, McKnight and Nemergut. This is an open-access article distributed under the terms of the Creative Commons Attribution Non Commercial License, which permits noncommercial use, distribution, and reproduction in other forums, provided the original authors and source are credited. 


\section{APPENDIX}

Table A1 | The range and mean of the number of sequences in each sample after applying the following filtering regime to the sequence dataset: removing OTUs represented by a single sequence, and removing OTUs present in only one sample.

OTU-picking method/identity threshold

uclust/97

cd-hit/97

cd-hit/90

cd-hit/95

cd-hit/99
Number of sequences after filtering

590-1392; mean: 889.8

575-1375; mean: 858.3

994-1734; mean: 1301.1

741-1542; mean: 1039.3

334-1009; mean: 550.7

Table A2 | Results from Mantel tests evaluating the relationship between bacterial community structure (UniFrac) and environmental variables.

Mantel $r$ statistic and corresponding $\boldsymbol{p}$-value, unweighted UniFrac vs. environmental variables ( $\boldsymbol{r}$ Statistic; $\boldsymbol{p}$-value)

\begin{tabular}{|c|c|c|c|c|c|c|c|}
\hline $\begin{array}{l}\text { OTU-picking method/OTU } \\
\text { threshold/No. sequences } \\
\text { sampled }\end{array}$ & \% Soil Moisture & pH & $\log (\% C)$ & Mn (ppm) & $\sqrt{ }$ As (ppm) & $\sqrt{ } \mathrm{Fe}(\mathrm{ppm})$ & $\%$ Silt \\
\hline uclust/97\%/100 & $-0.05 ; 0.55$ & $-0.17 ; 0.96$ & $0.38 ; \underline{0.002}$ & $0.59 ; \underline{0.001}$ & $-0.10 ; 0.71$ & $0.28 ; \underline{0.004}$ & $0.48 ; \underline{0.01}$ \\
\hline uclust/97\%/280 & $-0.05 ; 0.55$ & $-0.17 ; 0.96$ & $0.43 ; \underline{0.003}$ & $0.59 ; \underline{0.001}$ & $-0.09 ; 0.65$ & $0.27 ; \underline{0.010}$ & $0.49 ; \underline{0.01}$ \\
\hline uclust/97\%/580 & $0.003 ; 0.36$ & $-0.14 ; 0.91$ & $0.39 ; \underline{0.002}$ & $0.56 ; \underline{0.001}$ & $-0.08 ; 0.61$ & $0.27 ; \underline{0.005}$ & $0.49 ; \underline{0.01}$ \\
\hline cd-hit/97\%/100 & $-0.05 ; 0.53$ & $-0.15 ; 0.92$ & $0.42 ; \underline{0.004}$ & $0.59 ; \underline{0.001}$ & $-0.10 ; 0.71$ & $0.28 ; \underline{0.007}$ & $0.44 ; \underline{0.01}$ \\
\hline cd-hit/97\%/290 & $-0.04 ; 0.48$ & $-0.17 ; 0.96$ & $0.40 ; \underline{0.003}$ & $0.56 ; \underline{0.001}$ & $-0.11 ; 0.73$ & $0.24 ; \underline{0.008}$ & $0.41 ; \underline{0.02}$ \\
\hline cd-hit/97\%/575 & $-0.04 ; 0.54$ & $-0.12 ; 0.87$ & $0.35 ; \underline{0.008}$ & $0.53 ; \underline{0.003}$ & $-0.08 ; 0.63$ & $0.25 ; \underline{0.006}$ & $0.39 ; \underline{0.02}$ \\
\hline cd-hit/90\%/100 & $-0.07 ; 0.67$ & $-0.17 ; 0.97$ & $0.43 ; \underline{0.004}$ & $0.58 ; \underline{0.001}$ & $-0.15 ; 0.92$ & $0.27 ; \underline{0.006}$ & $0.42 ; \underline{0.01}$ \\
\hline cd-hit/90\%/360 & $-0.05 ; 0.55$ & $-0.16 ; 0.93$ & $0.38 ; \underline{0.007}$ & $0.57 ; \underline{0.001}$ & $-0.06 ; 0.55$ & $0.27 ; \underline{0.007}$ & $0.43 ; \underline{0.02}$ \\
\hline cd-hit/90\%/630 & $-0.04 ; 0.52$ & $-0.13 ; 0.88$ & $0.38 ; \underline{0.004}$ & $0.55 ; \underline{0.001}$ & $-0.07 ; 0.60$ & $0.25 ; \underline{0.008}$ & $0.45 ; \underline{0.01}$ \\
\hline cd-hit/90\%/990 & $-0.03 ; 0.47$ & $-0.11 ; 0.84$ & $0.35 ; \underline{0.009}$ & $0.53 ; \underline{0.002}$ & $-0.07 ; 0.62$ & $0.26 ; \underline{0.008}$ & $0.42 ; \underline{0.01}$ \\
\hline cd-hit/95\%/100 & $-0.01 ; 0.40$ & $-0.15 ; 0.92$ & $0.41 ; \underline{0.005}$ & $0.58 ; \underline{0.001}$ & $-0.16 ; 0.92$ & $0.25 ; \underline{0.006}$ & $0.38 ; \underline{0.03}$ \\
\hline cd-hit/95\%/420 & $-0.01 ; 0.40$ & $-0.18 ; 0.97$ & $0.41 ; \underline{0.005}$ & $0.56 ; \underline{0.001}$ & $-0.03 ; 0.43$ & $0.27 ; \underline{0.007}$ & $0.42 ; \underline{0.02}$ \\
\hline cd-hit/95\%/740 & $-0.03 ; 0.49$ & $-0.13 ; 0.87$ & $0.39 ; \underline{0.003}$ & $0.56 ; \underline{0.001}$ & $-0.07 ; 0.57$ & $0.28 ; \underline{0.005}$ & $0.42 ; \underline{0.02}$ \\
\hline cd-hit/99\%/100 & $-0.11 ; 0.81$ & $-0.19 ; 0.97$ & $0.39 ; \underline{0.005}$ & $0.58 ; \underline{0.001}$ & $-0.06 ; 0.57$ & $0.29 ; \underline{0.003}$ & $0.50 ; \underline{0.004}$ \\
\hline cd-hit/99\%/210 & $-0.06 ; 0.59$ & $-0.15 ; 0.91$ & $0.36 ; \underline{0.009}$ & $0.54 ; \underline{0.001}$ & $-0.09 ; 0.67$ & $0.24 ; \underline{0.011}$ & $0.49 ; \underline{0.003}$ \\
\hline cd-hit/99\%/320 & $-0.04 ; 0.48$ & $-0.13 ; 0.87$ & $0.35 ; \underline{0.003}$ & $0.55 ; \underline{0.001}$ & $-0.09 ; 0.68$ & $0.26 ; \overline{0.011}$ & $0.46 ; 0.01$ \\
\hline
\end{tabular}

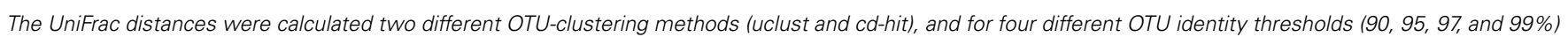

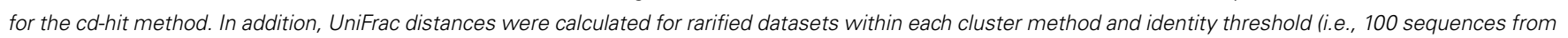
the each sample for cd-hit at 97\%). In the table the r statistics are listed, followed by the p-value.

p-values which are underlined are less than or equal to 0.05 . 

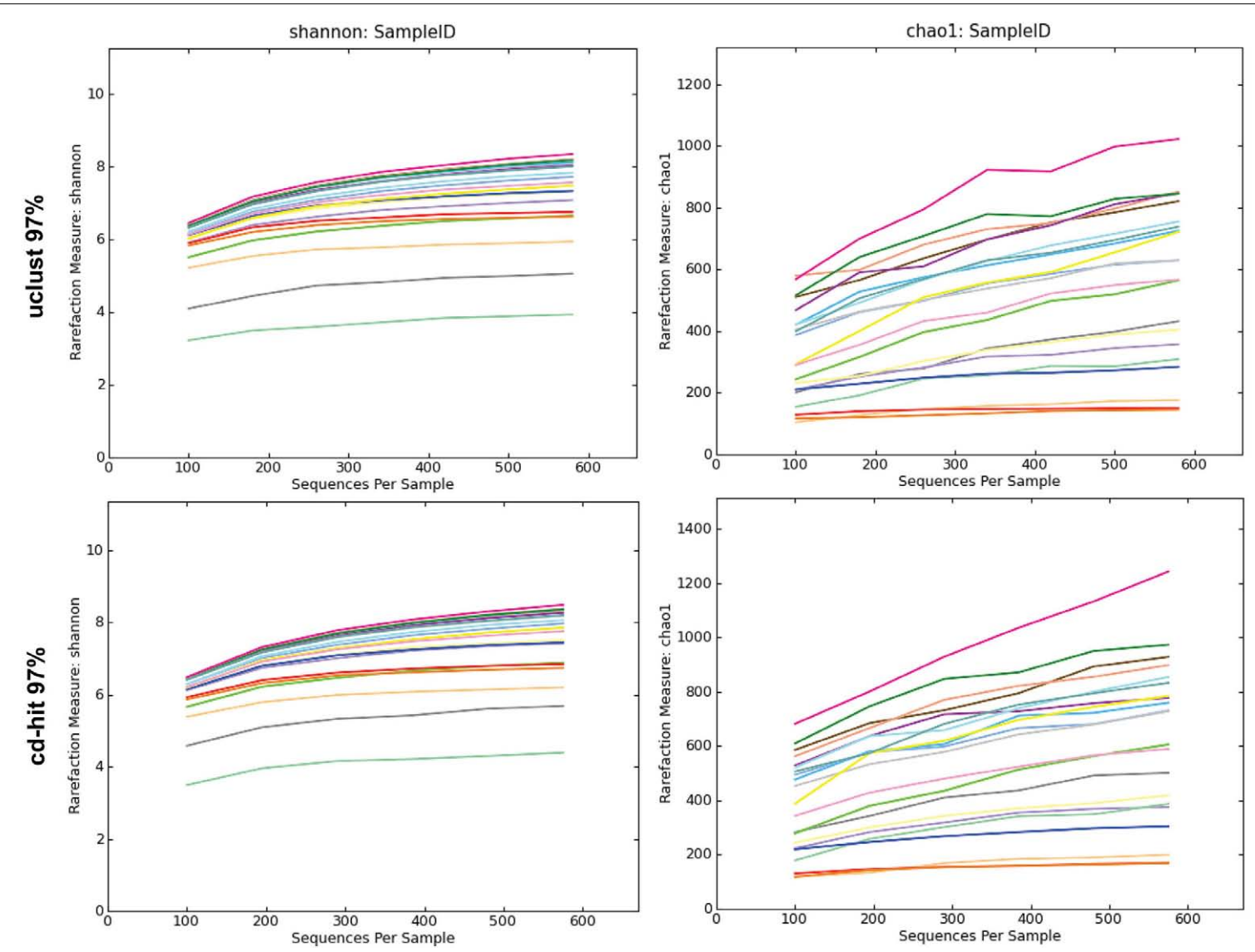

FIGURE A1 | Collector's curves for the Chao1 richness estimator and Shannon diversity index for two different OTU-picking methods. These

curves show that the alpha diversity of a majority of the samples approaches an asymptote, and there is a wide range in the alpha diversity of the samples. 